\title{
Microorganisms and spatial distribution of the sinkholes of the Yucatan Peninsula, underestimated biotechnological potential?
}

\author{
Pablo Antonio Moreno-Pérez (iD) 1, Marivel Hernández-Téllez², Ninfa Ramirez-Durán', \\ Marcela Gamboa-Angulo ${ }^{3}$ \& Keila Isaac-Olivé 1 \\ ${ }^{1}$ Faculty of Medicine, Autonomous University of the State of Mexico, Toluca, Mexico; ${ }^{2}$ Inter-American Institute of Technology and Water Sciences, \\ Autonomous University of the State of Mexico, Toluca, Mexico; and ${ }^{3}$ Biotechnology Unit, Scientific Research Center of Yucatan, A.C., Merida, Mexico
}

\author{
Keywords \\ biotechnology; groundwater; microorganism; \\ potential; sinkholes.

\section{Correspondence} \\ P. A. Moreno-Pérez, Faculty of Medicine, \\ Universidad Autónoma del Estado de México, \\ Toluca, Mexico.Email: saieto@hotmail.com \\ doi:10.1111/wej.12502
}

\begin{abstract}
Objective: To detect the spatial distribution of the sinkholes of the Peninsula of Yucatan (SPY) and identify those cenotes where microorganisms have been registered. Methods: The geographic coordinates of the SPYs were obtained from various databases, as well as from scientific publications relating to the terminology 'sinkholes', 'karst systems' and 'cenotes'. All coordinates were transformed into the Universal Transverse Mercator reference system (UTM) with datum WGS84. An infrared composite image was created with 432 RGB bands from the Landsat 8 satellite. The points with the location of the cenotes were imported into the Software TerrSet. Results: Total 1026 coordinates of sinkholes were recorded in the Yucatan Peninsula. In 18 sinkholes $(<2 \%)$, microorganisms have been recovered and identified in various taxonomic levels, and only 6 sinkholes $(<0.6 \%)$ has their biotechnological potential been evaluated. Conclusions: The microorganisms that inhabit the sinkholes of the Yucatan Peninsula are a reservoir with practically unexplored biotechnological potential.
\end{abstract}

\section{Introduction}

The Yucatan Peninsula (YP), is located in the Gulf of Mexico, it is a large platform consisting mainly of limestone, constituted by several hundred metres of subhorizontal thickness (Šafanda et al., 2005; Mejia-Ortiz et al., 2007). The limestone soil is highly permeable due to the combination of the dissolution mechanisms of calcium carbonate and collapse of the rock, this allows the fluvial waters to filter quickly into the aquifer, thus the absence of rivers on the surface (Polanco Rodríguez et al., 2017; Rosiles-González et al., 2017). The high permeability and porosity of the limestone soil of the YP has formed underground water reservoirs that flow slowly in a complex system of caverns (Kambesis and Coke, 2016). These are occasionally open to the surface forming large circular pools (Rubio et al., 2016), known in Mexico as 'cenotes', a word derived from the Mayan language, d'zonot. Their depth varies, reaching more than $100 \mathrm{~m}$ (Šafanda et al., 2005), and they are geographically distributed in almost all of the YP. The cenotes are classified in the lotics, which have a continuous water flow with transparent waters due to the low availability of nitrogen and phosphorus sources, limiting photosynthesis; lentics, which have less water exchange with the aquifer, are rich in nutrients and phytoplankton; they have four characteristic shapes: (A) pitchers, the connection with the surface is narrower than the diameter of the body of water, (B) cylindrical, vertical walls and the opening equals the diameter of the body of water, (C) watery, water deposits stagnant surface, (D) caves, which have a horizontal entrance and dry section (Schmitter-Soto et al., 2002; Mejia-Ortiz et al., 2007). There is a particularly remarkable pattern of semicircular distribution, $165 \mathrm{~km}$ in diameter, formed by a depression of 3-5 m deep and almost $5000 \mathrm{~m}$ wide; this characteristic is associated with the basin of the Chicxulub crater formed by the impact of a meteorite, Mexico (Hildebrand et al., 1995; Jet Propulsion Laboratory, 2003). The underground aquifer of the YP and its associated sinkholes which emerge to the surface, is one of the most extensive on the planet, on which diverse ecosystems depend (Bauer-Gottwein et al., 2011). The geomorphological characteristics of the sinkholes of the Yucatan Peninsula (SYP) and their underground connection to the cave systems condition the presence of particularly fragile ecosystems which provide habitat for numerous species (MacSwiney et al., 2007), some of which are endemic. Though the SYP are very abundant, very little knowledge of the microorganisms that inhabit it and of its biotechnological potential has been generated. The objective of this research was to detect the spatial distribution of the SYP, and identify those cenotes where microorganic taxa have been 
recovered and registered, as well as those that have been evaluated with biotechnological potential.

\section{Methods}

The study area was the Yucatan peninsula, comprising the states of Campeche, Yucatan and Quintana Roo, located in the Gulf of Mexico and the Caribbean Sea with an approximate area of $125000 \mathrm{~km}^{2}$. To determine the location of the SYPs, the geographic coordinates of the database of the (Quintana Roo Speleological Survey [QRSS], 2018; Secretariat of Human Development and the Environment [SEDUMA], 2018), and scientific publications related to the terminology 'cenotes', 'karst systems' and 'sinkholes' of the Yucatan Peninsula were consulted. All the coordinates were transformed to the Universal Transverse Mercator Reference System (UTM) with datum WGS84, a colour image was created in Infrared with bands 432 RGB of the Landsat 8 satellite, subsequently the points with the location of the cenotes were imported Software TerrSet Geospatial Monitoring and Modeling (Ronald, 2016), version 18.3.

\section{Results}

A total of 1026 coordinates of sinkholes were recorded in the states of Campeche, Yucatan and Quintana Roo, located in the Yucatan Peninsula, Mexico, of which 782 coordinates were recovered from SEDUMA, 205 from scientific publications and 39 from the QRSS (Fig. 1). Of the total number of sinkholes registered, in only 18 SYPs (Fig. 2) have microorganisms been recovered and identified at various taxonomic levels and only in 6 sinkholes of the total recorded $(<0.6 \%)$ have microorganisms been recovered in order to evaluate them biotechnologically.

In total, in the last 10 years, 104 taxa of microorganisms such as fungi, bacteria, cyanobacteria, microalgae, diatoms, as well as various taxonomic groups have been recovered and identified, of which 26 microorganisms have demonstrated a promising biotechnological potential (Table 1).

\section{Discussion}

According to the SEDUMA in the State of Yucatan, alone 2241 sinkholes have been identified, of which only 782 coordinates have been registered. In the State of Quintana Roo, only 39 sinkholes were georeferenced, though the location of more than 700 sinkholes has been recorded within more than a hundred cave systems, common in the state, such as the systems: Sac Actun, Dos Ojos, K'Oox Baal, Ox Bel Ha, Xunaan $\mathrm{Ha}$, Ponderosa and Murena-Aak Kimin, among others (Quintana Roo Speleological Survey, 2018). In the State of Campeche, only one register was found, despite the numerous reports of their presence in the state (Villalobos-Zapata et al., 2010; Vidal et al., 2015). The estimate of close to 10,000 SYP (Lara-Lara et al., 2008), may be based on the lack of knowledge of their

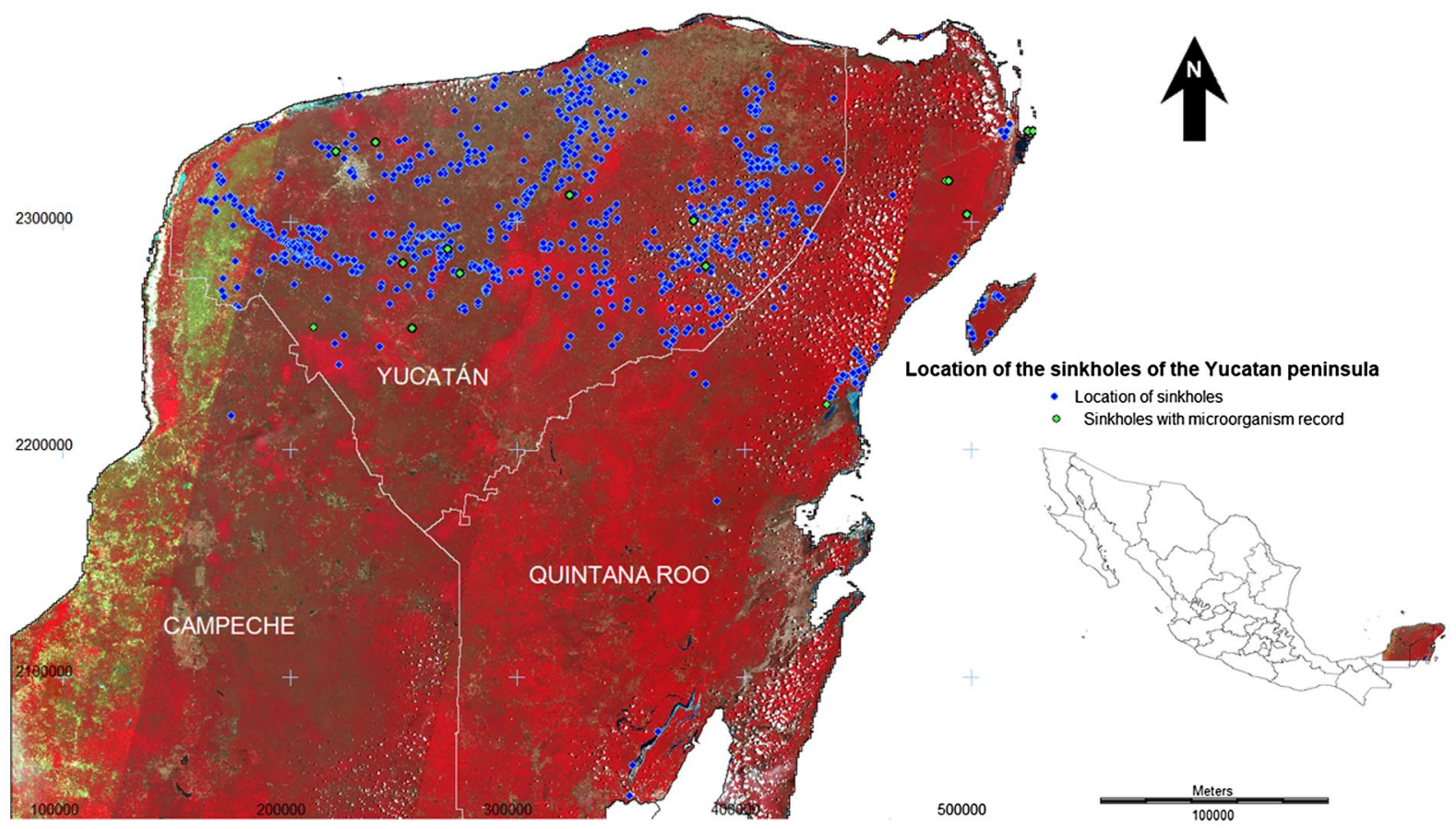

Fig. 1. Distribution of the SYP according to the coordinates of the UTM 

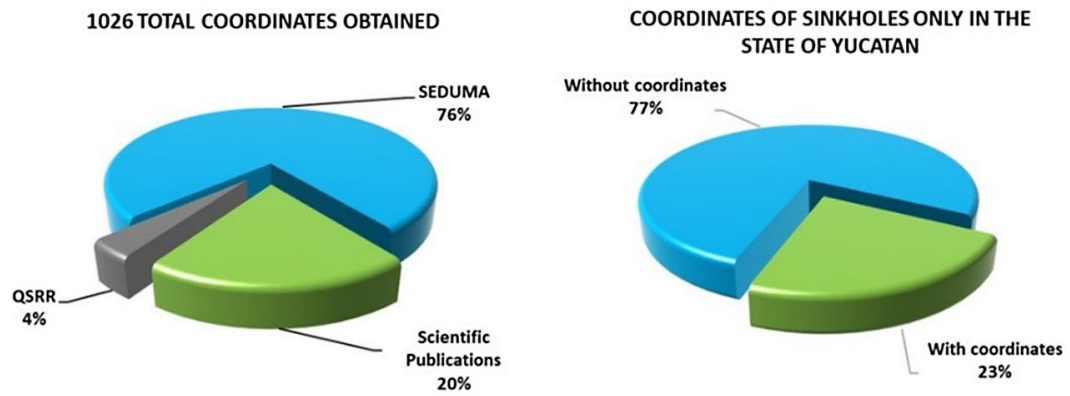

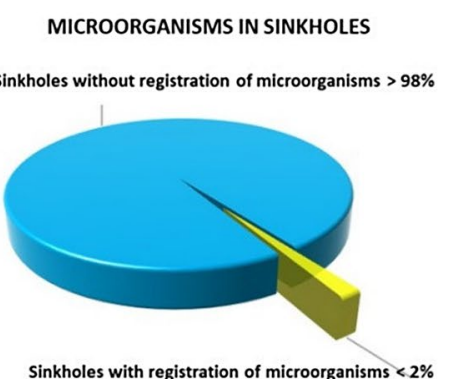

Fig. 2. Generalities of the sinkhole coordinates of the Yucatan Peninsula

location, due to the difficulty of access, because they are generally surrounded by a dense heterogeneous vegetation, a characteristic more evident in the states of Campeche and Quintana Roo (MacSwiney et al., 2007), consequently the assistance of a local guide is usually required for their location.

Though the biodiversity in the SYP is known, with the presence of phytoplankton, rotifers, cladocerans, copepods, macroscopic invertebrates (Iliffe, 1993), more than 45 species of crustaceans (Alvarez et al., 2015) and almost 40 species of fish (Schmitter-Soto and Gamboa-Pérez, 1996), in the present decade new taxa continue to be registered. However, research carried out on microorganisms living in these environments is scarce, without taking into account the reports due to anthropogenic contamination, they are found in plankton and phytoplankton (Sánchez et al., 2002; Aké-Castillo, 2014; Irola-Sansores et al., 2014; Szeroczyńska and Zawisza, 2015; Villafañe et al., 2015); fungal biomass (Gómez-Reyes et al., 2017); tropical microscopic fungi (Gamboa-Angulo et al., 2012; Moreno-Pérez et al., 2014; Moreno-Pérez et al., 2016); sediments from anchialine caves (Van Hengstum et al., 2009); and moderately halotolerant bacteria (De La Rosa-García et al., 2007). In comparison with the bacterioplankton estimations of $5.8 \times 10^{2}-8.0 \times 10^{3}$ cells $/ \mathrm{mL}$ in some sinkholes and their associated caves (Alcocer et al., 1999), the proportion of microorganisms identified is scarce; however, they have given notoriously relevant evidence of their biotechnological potential as mentioned below.

\section{Bioremediation agents}

In some SYPS (Medina-Moreno et al., 2014), polycyclic aromatic hydrocarbons (PAH) have been detected; these are compounds formed by two or more fused aromatic rings formed by carbon and hydrogen atoms and are generated when substances such as coal, oil and organic waste are partially burned, with anthropogenic activities being the main sources of contamination (Committee on Herbal Medicinal Products, 2016; Tongo et al., 2017). According to the United States Environmental Protection Agency (2009), PAH are considered priority pollutants due to the damage they cause to human health. Research conducted by Gómez-Reyes et al. (2017) found microbial biomass belonging to the genus Cladosporium ${ }^{\text {a }}$ which was able to degrade diesel and oil; additionally, LizardiJiménez et al. (2015), identified the bacterial genera Pseudomona ${ }^{a}$, Diplococcus a and Enterobacter ${ }^{\text {a }}$ (Table 1) as promissory ex situ bioremediators of hydrocarbons such as benzene, phenanthrene and naphthalene. Though the predictions suggest a significant decrease in global PAH emissions, estimated at $592 \mathrm{Gg}$ in 1995 (Shen et al., 2013), they are still present in the environment. Considering that microorganisms are essential components of ecological systems, the use of biotechnology in remediation processes has profitable advantages and environments.

\section{Natural pesticide producers}

Currently, more than 20,000 commercial products have been registered as pesticides by the United States Environmental Agency of Protection (Prieto Garcia et al., 2012). In 2012 alone, 500 thousand tons of pesticide active ingredients were used worldwide (Nava-Pérez et al., 2012) and there global trade is estimated at 50 billion dollars (Jouzani et al., 2017). Synthetic pesticides are persistent in the environment and biological systems, causing shortterm toxic effects in directly exposed organisms (Food and Agriculture Organization of the United Nations, 1996; Pesticide Action Network Europe, 2016). Each year they cause a million cases of poisoning and almost 20,000 deaths (Martínez-Valenzuela and Gómez-Arroyo, 2007). Investigations carried out on organic extracts of microscopic fungi (Moreno-Pérez et al, 2014; Moreno Pérez et al., 2016), showed that the extracts of Fusarium sp. KS-15a, Penicillium sp.OSE-61 $1^{\mathrm{a}}$ and Hypocrea lixii OSN-37 ${ }^{\mathrm{a}}$ inhibited the growth of the phytopathogens Xanthomonas campestris, Alternaria chrysanthemi and Mycosphaerella fijiensis at a minimum 
Table 1 Microorganisms registered in sinkholes or their associated caves in the last 10 years

\begin{tabular}{|c|c|c|c|c|}
\hline Organism & Strain & $\begin{array}{l}\text { Name of the } \\
\text { sinkhole }\end{array}$ & Location & Reference \\
\hline Diatom & Achnantidium sp. & Mumutdzonot & Tunkás, Yucatán & Irola-Sansores et al. (2014) \\
\hline Fungi & Acremonium pseudozeylanicum & X'kan ho ho che & Dzibilchaltún, Yucatán & Gamboa-Angulo et al. \\
\hline Fungi & Acremonium kiliense & Temozon & Temozón, Yucatán & $(2012)$ \\
\hline Fungi & Acremonium musicola & X'kan ho ho che & Dzibilchaltún, Yucatán & \\
\hline Bacteria & Aeromonas salmonicida $2 \times 71^{a}$ & N.S & $\begin{array}{l}\text { Dzibilchaltún o Temozón, } \\
\text { Yucatán }\end{array}$ & $\begin{array}{l}\text { De La Rosa-García et al. } \\
\text { (2007) }\end{array}$ \\
\hline Microcrustaceans & Alona sp. & $\begin{array}{l}\text { Cristal, Actum Ha, } \\
\text { Sian Ka'an }\end{array}$ & Tulum, Quintana Roo & $\begin{array}{l}\text { Szeroczyńska and Zawisza, } \\
\text { (2015 }\end{array}$ \\
\hline Fungi & Alternaria sp. & Temozon & Temozón, Yucatán & $\begin{array}{l}\text { Gamboa-Angulo et al. } \\
\text { (2012) }\end{array}$ \\
\hline Cianobacteria & Aphanocapsa delicatissima & Las Mojarras & Quintana Roo & Villafañe et al. (2015) \\
\hline Fungi & Aspergillus sp. & X'kan ho ho che & X’kanón, Yucatán & $\begin{array}{l}\text { Gamboa-Angulo et al. } \\
\text { (2012) }\end{array}$ \\
\hline Bacteria & Bacillus cereus $1 \mathrm{~T} 41^{\mathrm{a}}$ & N.S & $\begin{array}{l}\text { Dzibilchaltún o Temozón, } \\
\text { Yucatán }\end{array}$ & $\begin{array}{l}\text { De La Rosa-García et al. } \\
\text { (2007) }\end{array}$ \\
\hline Fungi & Beltrania rhombica & Temozon & Temozón, Yucatán & Gamboa-Angulo et al. \\
\hline Fungi & Beltrania sp. & Temozon & Temozón, Yucatán & $(2012)$ \\
\hline Fungi & Beltrania sp. & Temozon & Temozón, Yucatán & \\
\hline Fungi & Bionectria ochroleuca & Oxola & Homun, Yucatán & Moreno-Pérez et al. (2014) \\
\hline Bacilariofita & Brachysira microcephala & Las Mojarras & Quintana Roo & Villafañe et al. (2015) \\
\hline Bacteria & Burkholderia cepacia 1T31ª & N.S & $\begin{array}{l}\text { Dzibilchaltún o Temozón, } \\
\text { Yucatán }\end{array}$ & $\begin{array}{l}\text { De La Rosa-García et al. } \\
\text { (2007) }\end{array}$ \\
\hline Bacteria & Burkholderia gladioli 1X02a & N.S & $\begin{array}{l}\text { Dzibilchaltún o Temozón, } \\
\text { Yucatán }\end{array}$ & \\
\hline Bacteria & Burkholderia sp $1 \times 41^{a}$ & N.S & $\begin{array}{l}\text { Dzibilchaltún o Temozón, } \\
\text { Yucatán }\end{array}$ & \\
\hline Microcrustaceans & Camptocercus sp. & $\begin{array}{l}\text { Cristal, Actum Ha, } \\
\text { Sian Ka'an }\end{array}$ & Tulum, Quintana Roo & $\begin{array}{l}\text { Szeroczyńska and Zawisza, } \\
\text { (2015) }\end{array}$ \\
\hline Cianobacteria & Chroococcus minor & Leona Vicario & Quintana Roo & Villafañe et al. (2015) \\
\hline Fungi & Cladosporium cladosporioides & Temozon & Temozón, Yucatán & Gamboa-Angulo et al. \\
\hline Fungi & Cladosporium cladosporioides & X'kan ho ho che & X’kanón, Yucatán & $(2012)$ \\
\hline Fungi & Cladosporium sp. & X'kan ho ho che & X’kanón, Yucatán & \\
\hline Fungi & Cladosporium sp. & X'kan ho ho che & X’kanón, Yucatán & \\
\hline Fungi & Cladosporium spp..$^{a}$ & N.S & Cancun, Quintana Roo & Gómez-Reyes et al. (2017) \\
\hline Fungi & Clonostachys rosea & Temozon & Temozón, Yucatán & $\begin{array}{l}\text { Gamboa-Angulo et al. } \\
\text { (2012) }\end{array}$ \\
\hline Fungi & Clonostachys sp. & Oxola & Homun, Yucatán & Moreno-Pérez et al. (2014) \\
\hline Fungi & Colletotrichum sp. & X'kan ho ho che & X’kanón, Yucatán & $\begin{array}{l}\text { Gamboa-Angulo et al. } \\
\text { (2012) }\end{array}$ \\
\hline Protista & Criptofitas & Calcuch & Sabacché, Yucatán & Irola-Sansores et al. (2014) \\
\hline Clorofita & Cryptomonas curvata & Leona Vicario & Quintana Roo & Villafañe et al. (2015) \\
\hline Fungi & Cylindrocarpon congoense & X'kan ho ho che & X’kanón, Yucatán & Gamboa-Angulo et al. \\
\hline Fungi & Cylindrocarpon sp. XH9B & X'kan ho ho che & X’kanón, Yucatán & $(2012)$ \\
\hline Bacterium & Diplococcus sp..$^{a}$ & N.S & Cancun, Quintana Roo & $\begin{array}{l}\text { Medina-Moreno et al. } \\
\text { (2014) }\end{array}$ \\
\hline Bacterium & Diplococcus & Xca-ha & Playa del Carmen, Quintana Roo & $\begin{array}{l}\text { Medina-Moreno et al. } \\
\text { (2014) }\end{array}$ \\
\hline Bacterium & Diplococcus spp. & N.S & Cancun, Quintana Roo & Gómez-Reyes et al. (2017) \\
\hline Diatomea & Diploneis sp. & Mumutdzonot & Tunkás, Yucatán & Irola-Sansores et al. (2014) \\
\hline Fungi & Emericella variecolor & X'kan ho ho che & X’kanón, Yucatán & $\begin{array}{l}\text { Gamboa-Angulo et al. } \\
\text { (2012) }\end{array}$ \\
\hline Bacilariofita & Encyonopsis cesatii & Leona Vicario & Quintana Roo & Villafañe et al. (2015) \\
\hline Bacilariofita & Encyonopsis cesatii & Las Mojarras & Quintana Roo & \\
\hline Bacterium & Enterobacter aerogenes ${ }^{a}$ & N.S & Cancun, Quintana Roo & $\begin{array}{l}\text { Medina-Moreno et al. } \\
\text { (2014) }\end{array}$ \\
\hline
\end{tabular}


Table 1 (Continued)

\begin{tabular}{|c|c|c|c|c|}
\hline Organism & Strain & $\begin{array}{l}\text { Name of the } \\
\text { sinkhole }\end{array}$ & Location & Reference \\
\hline Bacterium & Enterobacter spp. & N.S & Cancun, Quintana Roo & Gómez-Reyes et al. (2017) \\
\hline Cianobacteria & Epigloeosphaera glebulenta & Las Mojarras & Quintana Roo & Villafañe et al. (2015) \\
\hline Bacterium & Escherichia coli & N.S & Cancun, Quintana Roo & $\begin{array}{l}\text { Medina-Moreno et al. } \\
\qquad(2014)\end{array}$ \\
\hline Fungi & Fomitopsis meliae & Kikal & Homun, Yucatán & Moreno-Pérez et al. (2014) \\
\hline Fungi & Fusarium solani & Oxola & Homun, Yucatán & \\
\hline Fungi & Fusarium solani & Oxola & Homun, Yucatán & \\
\hline Fungi & Fusarium solani & Kikal & Homun, Yucatán & \\
\hline Fungi & Fusarium sp. & X'kan ho ho che & X’kanón, Yucatán & Gamboa-Angulo et al. \\
\hline Fungi & Fusarium sp. & X'kan ho ho che & X’kanón, Yucatán & $(2012)$ \\
\hline Fungi & Fusarium sp. TA54a & Temozon & Temozón, Yucatán & \\
\hline Fungi & Fusarium sp. & Temozon & Temozón, Yucatán & \\
\hline Fungi & Fusarium sp. XH1Gaa & X'kan ho ho che & X’kanón, Yucatán & \\
\hline Fungi & Fusarium sp. & X'kan ho ho che & X’kanón, Yucatán & \\
\hline Fungi & Fusarium sp. & X'kan ho ho che & X’kanón, Yucatán & \\
\hline Fungi & Fusarium sp. & X'kan ho ho che & X’kanón, Yucatán & \\
\hline Fungi & Fusarium sp. & X'kan ho ho che & X’kanón, Yucatán & \\
\hline Fungi & Fusarium sp. & Oxola & Homun, Yucatán & Moreno-Pérez et al. (2014) \\
\hline Fungi & Fusarium sp. KS-15ª & Kikal & Homun, Yucatán & \\
\hline Fungi & Fusarium sp. & Oxola & Homun, Yucatán & \\
\hline Fungi & Fusarium sp. & Kikal & Homun, Yucatán & \\
\hline Fungi & Gliocladium penicillioides TH21 & Temozon & Temozón, Yucatán & Gamboa-Angulo et al. \\
\hline Fungi & Gliocladium sp. TH16a & Temozon & Temozón, Yucatán & $(2012)$ \\
\hline Fungi & Hypocrea lixii OSN-37a & Oxola & Homun, Yucatán & Moreno-Pérez et al. (2014) \\
\hline Diatom & Mastogloia spp. & Mumutdzonot & Tunkás, Yucatán & IIrola-Sansores et al. (2014) \\
\hline Fungi & Minteriella cenotigena & N.S & Merida, Yucatán & Heredia et al. (2013) \\
\hline Fungi & Monodictys sp. & Oxola & Homun, Yucatán & Moreno-Pérez et al. (2014) \\
\hline Clorofita & Monoraphidium irregulare & Las Mojarras & Quintana Roo & Villafañe et al. (2015) \\
\hline Fungi & Myrothecium sp. & Temozon & Temozón, Yucatán & $\begin{array}{l}\text { Gamboa-Angulo et al. } \\
\text { (2012) }\end{array}$ \\
\hline Microalgae & Ochromonas sp. & Nohmozón & Pixyah, Yucatán & Irola-Sansores et al. (2014) \\
\hline Microcrustaceans & Oxyurella sp. & $\begin{array}{l}\text { Cristal, Actum Ha, } \\
\text { Sian Ka'an }\end{array}$ & Tulum, Quintana Roo & $\begin{array}{l}\text { Szeroczyńska and Zawisza. } \\
\text { (2015) }\end{array}$ \\
\hline Fungi & Papulaspora pallidula & X'kan ho ho che & X’kanón, Yucatán & Gamboa-Angulo et al. \\
\hline Fungi & Penicillium citrinum & X'kan ho ho che & X’kanón, Yucatán & (2012) \\
\hline Fungi & Penicillium sp. OSE-61ª & Oxola & Homun, Yucatán & Moreno-Pérez et al. (2014) \\
\hline Fungi & Penicillium sp. & Kikal & Homun, Yucatán & \\
\hline Fungi & Pestalotiopsis maculans & X'kan ho ho che & X’kanón, Yucatán & $\begin{array}{l}\text { Gamboa-Angulo et al. } \\
\text { (2012) }\end{array}$ \\
\hline Fungi & Pestalotiopsis mangiferae $\mathrm{OH}-02$ & Oxola & Homun, Yucatán & Moreno-Pérez et al. (2014) \\
\hline Cianobacteria & Phormidium sp. & Mumutdzonot & Tunkás, Yucatán & Irola-Sansores et al., (2014) \\
\hline Bacterium & Photobacterium sp. ${ }^{\text {a }}$ & N.S & $\begin{array}{l}\text { Dzibilchaltún o Temozón, } \\
\text { Yucatán }\end{array}$ & $\begin{array}{l}\text { De La Rosa-García et al. } \\
\text { (2007) }\end{array}$ \\
\hline Cianobacteria & Pseudanabaena limnetica & Las Mojarras & Quintana Roo & Villafañe et al. (2015) \\
\hline Bacterium & Pseudomonas sp. ${ }^{a}$ & N.S & Cancun, Quintana Roo & $\begin{array}{l}\text { Medina-Moreno et al. } \\
\qquad(2014)\end{array}$ \\
\hline Bacterium & Pseudomonas sp. & Xca-ha & Playa del Carmen, Quintana Roo & $\begin{array}{l}\text { Medina-Moreno et al. } \\
\qquad(2014)\end{array}$ \\
\hline Bacterium & Pseudomonas aeruginosa $2 \mathrm{~T}_{16}^{\mathrm{a}}$ & N.S & $\begin{array}{l}\text { Dzibilchaltún o Temozón, } \\
\text { Yucatán }\end{array}$ & $\begin{array}{l}\text { De La Rosa-García et al. } \\
\text { (2007) }\end{array}$ \\
\hline Bacterium & Pseudomonas luteola 1T17a & N.S & $\begin{array}{l}\text { Dzibilchaltún o Temozón, } \\
\text { Yucatán }\end{array}$ & \\
\hline Bacterium & Pseudomonas spp. & N.S & Cancun, Quintana Roo & Gómez-Reyes et al. (2017) \\
\hline
\end{tabular}


Table 1 (Continued)

\begin{tabular}{|c|c|c|c|c|}
\hline Organism & Strain & $\begin{array}{l}\text { Name of the } \\
\text { sinkhole }\end{array}$ & Location & Reference \\
\hline Fungi & Pseudorobillarda sojae & Oxola & Homun, Yucatán & Moreno-Pérez et al. (2014) \\
\hline Fungi & Rhizoctonia solani OSE-73a & Oxola & Homun, Yucatán & \\
\hline Fungi & Scopulariopsis sp. & Kikal & Homun, Yucatán & \\
\hline Bacterium & Serratia plymuthica 1T23a & N.S & $\begin{array}{l}\text { Dzibilchaltún o Temozón, } \\
\text { Yucatán }\end{array}$ & $\begin{array}{l}\text { De La Rosa-García et al. } \\
\text { (2007) }\end{array}$ \\
\hline Bacterium & Shewanella putrefaciens $2 \mathrm{~T} 41^{\mathrm{a}}$ & N.S & $\begin{array}{l}\text { Dzibilchaltún o Temozón, } \\
\text { Yucatán }\end{array}$ & \\
\hline Fungi & Stachybotrys nephrospora & Temozon & Temozón, Yucatán & Gamboa-Angulo et al. \\
\hline Fungi & Stagonospora sp. & Temozon & Temozón, Yucatán & $(2012)$ \\
\hline Bacterium & Stenotrophomonas maltophilia $1 \times 25^{\mathrm{a}}$ & N.S & $\begin{array}{l}\text { Dzibilchaltún o Temozón, } \\
\text { Yucatán }\end{array}$ & $\begin{array}{l}\text { De La Rosa-García et al. } \\
\text { (2007) }\end{array}$ \\
\hline Bacterium & Stenotrophomonas sp. 1T202 & N.S & $\begin{array}{l}\text { Dzibilchaltún o Temozón, } \\
\text { Yucatán }\end{array}$ & \\
\hline Clorofita & Tetrastrum komarekii & Leona Vicario & Quintana Roo & Villafañe et al. (2015) \\
\hline Microalgae & Thompsodinium intermedium & Dzityá o Chen-Ha & Dzityá, Yucatán & Aké-Castillo (2014) \\
\hline Alga & Tribonema sp. & Mumutdzonot & Tunkás, Yucatán & Irola-Sansores et al. (2014) \\
\hline Fungi & Verticillium sp. TH28 & Temozon & Temozón, Yucatán & Gamboa-Angulo et al. \\
\hline Fungi & Verticillium sp. & Temozon & Temozón, Yucatán & (2012) \\
\hline Bacterium & Vibrio sp. & N.S & Cancun, Quintana Roo & Lizardi-Jiménez et al. (2015) \\
\hline Bacterium & Vibrio sp. & Xca-ha & Playa del Carmen, Quintana Roo & $\begin{array}{l}\text { Medina-Moreno et al. } \\
\text { (2014) }\end{array}$ \\
\hline Fungi & Volutella sp. & Temozon & Temozón, Yucatán & Gamboa-Angulo et al. \\
\hline Fungi & Volutella sp. & Temozon & Temozón, Yucatán & (2012) \\
\hline Fungi & Volutella sp. & Temozon & Temozón, Yucatán & \\
\hline Fungi & Zygosporium minus & Temozon & Temozón, Yucatán & \\
\hline
\end{tabular}

N.S = not specified

${ }^{a}$ Organisms evaluated with notorious biotechnological potential.

inhibitory concentration (MIC) of 25, 500 and $1000 \mu \mathrm{g} / \mathrm{mL}$, respectively. Additionally, they determined the antagonistic capacity of the species $H$. lixii OSN-37ª, Rhizoctonia solani OSE-73a and Pestalotiopsis mangiferae $\mathrm{OH}-02^{\mathrm{a}}$ (Table 1) against the phytopathogens Colletrotrichum gloeosporioides, Corynespora cassiicola, Curvularia sp. and Fusarium spp., inhibiting the growth of at least three of the four phytopathogens by more than $50 \%$. The trade in natural pesticides is estimated at 3.5 billion dollars with an annual growth of $16 \%$ (Jouzani et al., 2017). The increasingly demanding market regarding food safety and health regulations worldwide will continue to drive this trend.

\section{Producers of antimicrobial compounds}

According to the World Health Organization (2017), the research and development of new antibiotics to address the resistance of microorganisms to current antibiotics, which is estimated to cause 700000 deaths per year. Research conducted by Gamboa-Angulo et al. (2012; 2013) evaluated the effects of extracts of microscopic fungi, against Mycobacterium tuberculosis, which in 2016 caused more than 10 million infected and 1.7 million deaths (World Health Organization, 2015), finding that the extracts of the species Cylindrocarpon sp. XH9Ba ${ }^{a}$ Fusarium sp. TA54 and $\mathrm{XH} 1 \mathrm{Ga}^{\mathrm{a}}$, Gliocladium penicillioides $\mathrm{TH} 21^{\mathrm{a}}$, Gliocladium sp. $\mathrm{TH}_{16} 6^{\mathrm{a}}$ and Verticillium sp.TH28, inhibited the growth of M. tuberculosis with an MIC of $1.56-25 \mu \mathrm{g} / \mathrm{mL}$; they also evaluated them against promastigotes of Leishmania mexicana, which causes ulcerative lesions and disfiguring scars, finding that Fusarium sp. TA54 a and Verticillium sp. TH28 (Table 1), caused a mortality in L. mexicana of IC50 $=14.23-$ $100 \mu \mathrm{g} / \mathrm{mL}$ and $\mathrm{IC} 100=50-100 \mu \mathrm{g} / \mathrm{mL}$, respectively. In addition, they evaluated the antimicrobial activity of extracts of 96 fungal species against Bacillus subtilis, Candida albicans and Staphylococcus aureus among other pathogens, finding that 78 had activity against at least one of the evaluated targets. On the other hand, research conducted by De la Rosa-García et al. (2007) found moderately halotolerant bacteria of the genus Aeromonasa, Bacillusa, Burkholderia ${ }^{\mathrm{a}}$, Photobacterium ${ }^{\mathrm{a}}$, Pseudomonas ${ }^{\mathrm{a}}$, Serratia ${ }^{\mathrm{a}}$, Shewanella and Stenotrophomonas ${ }^{\mathrm{a}}$ (Table 1) which presented a broad spectrum of antimicrobial action against the pathogens B. subtilis (ATCC-6633), C. albicans (ATCC10231), Erwinia carotovora subp. Carotovorum (ATCC-138) Pseudomonas syringae pathovar. Pisi (ATCC-11043), S. aureus (ATCC-6536) and Xanthomonas campestris pathovar. Carotae (ATCC-10547). 
Despite the increase in microorganisms resistant to current antibiotics, the number of antibiotics available is limited; the urgent search for new antimicrobial drugs is an alternative to this problem (Naradala et al., 2016). Considering that the world market in medicines is estimated at almost 1.2 trillion dollars for the year 2016 (Institute for Healthcare Informatics, 2012), obtaining compounds or molecules with potential to develop drugs has an enormous biotechnological potential.

The relevance of the SYP is the distribution, location and quantity of these aquifer bodies, associated with their microorganisms with demonstrated biotechnological potential. Given the ignorance of the totality of the sinkholes that are found in YP, their associated environments, as well as the diversity of practically unknown microorganisms that inhabit them, it is necessary to manage the conservation and environmental protection of these environments. The sinkholes are a promising model of bioremediation of emerging pollutants, industrial and hydrocarbons in aquatic environments, for their immediate application in environmental contingencies. Obtaining natural compounds 'friendly to the environment' obtained from these microorganisms, as pesticides of natural origin, represent an alternative for their implementation in crops of economic interest and the production of safe food for health. Decreasing the use of synthetic chemical compounds with proven harm to human health. In addition to obtaining novel antimicrobials, as an alternative to combat pathogenic bacteria that are resistant to most commercially available drugs, mainly those belonging to the ESKAPE group: Enterococcus faecium, Staphylococcus aureus, Klebsiella, Acinetobacter baumannii, Pseudomonas aeruginos and Escherichia coli, which are the main causes of nosocomial infections or intra-hospital infections worldwide.

\section{Conclusions}

(1) The first step is to create a systematic proposal of recognition, identification, registration and conservation of microscopic species of these environments.

(2) SYP is a reservoir of practically unexplored microorganisms and the paucity of microbiological research in these environments has limited the biotechnological potential as an alternative to reduce the negative impact of many current concerns. The microorganisms that inhabit these environments are a viable alternative which, as yet has been poorly explored.

(3) The results allow concluding that there is no complete database with the georeferencing of the location of the SPYS in each State and municipality of the Yucatan Peninsula, and even less is known regarding their location in the states of Campeche and Quintana Roo.

\section{Acknowledgement}

This work was carried out as part of the activities of the Red Temática CONACYT 'Gestión de la Calidad y Disponibilidad del Agua'.

\section{Conflict of interest}

The authors state that they do not have any type of conflict of interests.

To submit a comment on this article please go to http:// mc.manuscriptcentral.com/wej. For further information please see the Author Guidelines at wileyonlinelibrary.com

\section{References}

Aké-Castillo, J.A. (2014) Thompsodinium intermedium (Dinophyceae), a freshwater planktonic species in Mexico. Revista Mexicana de Biodiversidad, 85(3), 953-956. Available at: https://doi.org/10.7550/rmb.41270.

Alcocer, J., Lugol, A., Sánchez, M.R.Escobar, E., and Sánchez, M. (1999) Bacterioplankton from cenotes and anchialine caves of Quintana Roo, Yucatan Peninsula, Mexico. Revista de Biología Tropical, 47(Culver 1994), 19-25.

Alvarez, F., lliffe, T.M., Benitez, S., Brankovits, D. and Villalobos, J.L. (2015) New records of anchialine fauna from the New records of anchialine fauna from the Yucatan Peninsula. Check List, 11 (January). Available at: https://doi.org/10.15560/11.1.1505.

Bauer-Gottwein, P., Gondwe, B.R.N., Charvet, G., Marín, L.E., Rebolledo-Vieyra, M. and Merediz-Alonso, G. (2011) Review: The Yucatán Peninsula karst aquifer, Mexico. Hydrogeology Journal, 19(3), 507-524. Available at: https ://doi.org/10.1007/s10040-010-0699-5.

Committee on Herbal Medicinal Products (HMPC) (2016) European Medicines Ageny. Available at: http://www.ema. europa.eu/docs/en_GB/document_library/Scientific_guide line/2016/06/WC500209467.pdf.

De la Rosa-García, S.C., Muñoz-García, A.A., Barahona-Pérez, L.F. and Gamboa-Angulo, M.M. (2007) Antimicrobial properties of moderately halotolerant bacteria from cenotes of the Yucatan peninsula. Letters in Applied Microbiology, 45(3), 289-294. Available at: https://doi. org/10.1111/j.1472-765X.2007.02185.X.

Food and Agriculture Organization of the United Nations (1996) Eliminación de Grandes Cantidades de Plaguicidas en Desuso en los Países en Desarrollo. Available at: http://www.fao.org/docrep/W1604S/W1604S00.htm [Accessed 5 May 2017].

Gamboa-Angulo, M., De la Rosa, S.D.C., Heredia-Abarca, G. and Medina-Baizabal, I.L. (2012) Antimicrobial screening of tropical microfungi isolated from sinkholes located in the Yucatan peninsula, México. African Journal of Microbiology Research, 6(1), 2305-2312. Available at: https://doi.org/10.5897/AJMR11.1129. 
Gamboa-Angulo, M., Molina-Salinas, G.M., Chan-Bacab, M., Peraza-Sánchez, S.R., Heredia, G., De la Rosa-García, S.C. and Reyes-Estebanez, M. (2013) Antimycobacterial and antileishmanial effects of microfungi isolated from tropical regions in México. Parasitology Research, 112(2), 559-66. Available at: https://doi: 10.1007/s00436-0123167-4.

Gómez-Reyes, R., Medina-Moreno, S.A., Jiménez-González, A. and Lizardi-Jiménez, M.A. (2017) Aislamiento y análisis cualitativo de biomasa microbiana fúngica degradadora de hidrocarburos de un cenote de quintana roo. Revista Internacional de Contaminacion Ambiental, 33, 53-61. Available at: https://doi.org/10.20937/RICA.2017.33. esp01.05.

Heredia, G., Ruiz, R.F.C., Arias, R.M., Gamboa-Angulo, M. and Susana, C. (2013) Minteriella cenotigena anam. gen. \& sp. nov. from submerged plant material in Mexico. Mycological Progress, 12(2), 271-275. Available at: https ://doi.org/10.1007/s11557-012-0831-0.

Hildebrand, A.R., Pilkington, M., Connors, M., Ortiz-Aleman, C. and Chavez, R.E. (1995) Size and structure of the Chicxulub crater revealed by horizontal gravity gradients and cenotes. Nature, 376, 415-417. Available at: https:// doi.org/10.1038/376415a0.

Iliffe, T.M. (1993) Fauna Troglobia Acuatica de la Peninsula de Yucatin. Biodiversidad Marina y Costera de México, 865.

IMS Institute for Healthcare Informatics (2012) The Global Use of Medicines: Outlook Through 2016. Report by the IMS Institute for Healthcare Informatics. Available at: http://apps.who.int/medicinedocs/en/d/Js20306en/ [Accessed 6 January 2018].

Irola-Sansores, E.D., Almazán-Becerril, A., HernándezTerrones, L.M., Ortega-Camacho, D., Escobar-Morales, S. and Delgado-Pech, B. (2014) Limitación por fósforo de la biomasa fitoplanctónica en cenotes de la península de Yucatán. In: Botello, AV, von Osten, JR, Benítez, JA and Gold-Bouchot, G. (Eds.) Contaminación e impacto ambiental: diagnóstico y tendencias. UAC, UNAM-ICMYL, CINVESTAV-Unidad Mérida, pp. 41-54.

Jet Propulsion Laboratory (2003) National Aeronautics and Space Administration (NASA), California Institute Laboratory. Available at: https://photojournal.jpl.nasa.gov/ catalog/PIA03380.

Jouzani, G.S., Valijanian, E. and Sharafi, R. (2017) Bacillus thuringiensis: a successful insecticide with new environmental features and tidings. Applied Microbiology and Biotechnology, 101(7), 2691-2711. Available at: https://doi.org/10.1007/s00253-017-8175-y.

Kambesis, P.N. and Coke, J.I. (2016) The Sac Actun System, Quintana Roo, Mexico. Boletín Geológico y Minero, 127(1), 177-192. Available at: http://www.igme.es/Bolet in/2016/127_1/BG_127-1_Art-12.pdf.

Lara-Lara, J.R., Arreola Lizárraga, A., Calderón Aguilera, L.E., Camacho Ibar V.F., De la Lanza Espino G., Escofet Giansone A.M., et al. (2008) Los ecosistemas costeros, insulares y epicontinentales, en Capital natural de
México, vol. I: Conocimiento actual de la biodiversidad. Edited by Comisión Nacional para el Conocimiento y Uso de la Biodiversidad (CONABIO).

Lizardi-Jiménez, M.A., Leal-Bautista, R.M., Ordaz, A. and Reyna-Velarde, R. (2015) Airlift bioreactors for hydrocarbon water pollution remediation in a tourism development pole. Desalination and Water Treatment, 54(1), 44-49. Available at: https://doi.org/10.1080/19443 994.2013.876670.

MacSwiney, M.C., Vilchis, P., Clarke, F.M. and Racey, P.A. (2007) The importance of cenotes in conserving bat assemblages in the Yucatan, Mexico. Biological Conservation, 136(4), 499-509. Available at: https://doi. org/10.1016/j.biocon.2006.12.021.

Martínez-Valenzuela, C. and Gómez-Arroyo, S. (2007) Riesgo genotóxico por exposicion a plaguicidas en trabajadores agrícolas. Revista Internacional de Contaminación Ambiental, 23(4), 185-200.

Medina-Moreno, S.A., Jiménez-González, A., Gutiérrez-Rojas, M. and Lizardi-Jiménez, M. A. (2014) Hydrocarbon pollution studies of underwater sinkholes along Quintana Roo as a function of tourism development in the Mexican Caribbean. Revista Mexicana de Ingenieria Quimica, 13(2), 509-516.

Mejia-Ortiz, L.M., Yanez, G., Lopez-Mejia, M. and ZarzaGonzalez, E. (2007) Cenotes (anchialine caves) on Cozumel Island, Quintana Roo, México. Journal of Cave and Karst Studies, 69(2), 250-255.

Moreno Pérez, P., Gamboa-Angulo, M., Heredia, G., Canto Canché, B., Rodriguez García, C.M., Medina Baizabal, I.L. and Peraza Echeverría, L. (2016) Antimicrobial evaluation of extracts obtained from tropical micromycetes against phytopathogens. Phyton-International Journal of Experimental Botany, 85(130), 7-14.

Moreno-Pérez, P., Gamboa-Angulo, M., Heredia, G., Canto-Canché, B., Rosado-Vallado, M., Medina-Baizabal, I.L., et al. (2014) Antagonistic properties of Micromycetes isolated from sinkholes of the Yucatán Península against fungal phytopathogens. Revista Mexicana de Micología, 40, 27-36 Available at: https://www.researchgate.net/ publication/317438288_Antagonistic_properties_of_micro mycetes_isolated_from_sinkholes_of_the_Yucatan_Penin sula_against_fungal_phytopathogens.

Naradala, P., Vijayalakshmi, M., Mangamuri, U. and Kavi Kishore, P.B. (2016) Exploration of potent actinobacterium nocardiopsis halotolerans VJPR-2 isolated from mangrove habitats. Asian Journal of Pharmaceutical and Clinical Research, 9(4), 113-117.

Nava-Pérez, E., García-Gutiérrez, C., Camacho-Báez, J.R. and Vázquez-Montoya, E.L. (2012) Bioplaguicidas: una opción para el control biológico de plagas. Ra Ximhai, 8(3), 41-49.

Pesticide Action Network Europe (2016) Pesticide Environmental Risk Assessment: Environment unprotected? Available at: https://www.pan-europe.info/ sites/pan-europe.info/files/20161115_Angeliki_Envir onment_unprotected.pdf [Accessed: 27 June 2017]. 
Polanco Rodríguez, Á.G., López, M.I.R., Casillas, T.A.D., León, J.A.A., Prusty, B.A.K. and Cervera, F.J.Á. (2017) Levels of persistent organic pollutants in breast milk of Maya women in Yucatan, Mexico. Environmental Monitoring and Assessment, 189(2). Available at: https:// doi.org/10.1007/s10661-017-5768-y.

Prieto Garcia, F., Ascencio, S.Y.C., Oyarzun, J.G., Hernandez, A.C. and Alavarado, P.V. (2012) Pesticides: classification, uses and toxicity. Measures of exposure and genotoxic risks. Journal of Research in Environmental Science and Toxicology, 1(11), 2315-5698 Available at: http://www. interesjournals.org/JREST.

Quintana Roo Speleological Survey (2018) Cuevas por longitud. Available at: https://caves.org/project/qrss/qrlon gesp.htm [Accessed 13 September 2017].

Ronald, E.J. (2016) Software TerrSet. Worcester, MA, USA. Rosiles-González, G., Ávila-Torres, G., Moreno-Valenzuela, O.A., Acosta-González, G., Leal-Bautista, R.M., GrimaldoHernández, C.D., et al. (2017) Occurrence of pepper mild mottle virus (PMMoV) in groundwater from a karst aquifer system in the Yucatan Peninsula, Mexico. Food and Environmental Virology, 9(4), 487-497. Available at: https://doi.org/10.1007/s12560-017-9309-1.

Rubio, F., Rolán, E., Worsaae, K., Martínez, A. and Gonzalez, B.C. (2016) Description of the first anchialine gastropod from a Yucatán cenote, Teinostoma brankovitsi n. sp. (Caenogastropoda: Tornidae), including an emended generic diagnosis. Journal of Molluscan Studies, 82(1), 169-177. Available at: https://doi.org/10.1093/mollus/ eyv049.

Šafanda, J., Heidinger, P., Wilhelm, H. and Čermák, V. (2005) Fluid convection observed from temperature logs in the karst formation of the Yucatán Peninsula, Mexico. Journal of Geophysics and Engineering, 2(4), 326-331. Available at: https://doi.org/10.1088/1742-2132/2/4/S05.

Sánchez, Malinali, Javier Alcocer, E.E. and Lugo, L. (2002) Phytoplankton of cenotes and anchialine caves along a distance gradient from the northeastern coast of Quintana Roo, Yucatan Peninsula. Hydrobiologia, 467, 79-89. Available at: https://doi.org/10.1023/A:10149 36714964.

Schmitter-Soto, J.J. and Gamboa-Pérez, H.C. (1996) Composición y distribución de peces continentales en el sur de Quintana Roo, Península de Yucatán, México. Revista de Biologia Tropical, 44(1), 199-212.

Schmitter-Soto, J.J., Comin, E.F.A., Escobar-Briones, J., Herrera-Silveira, J., Alcocer, E., Suárez-Morales, M., et al. (2002) Hydrogeochemical and biological characteristics of cenotes in the Yucatan Peninsula. Hydrobiologia, 467, 215-228.

Secretariat of Human Development and the Environment (2018) Cenotes y Grutas. Available at: http://www. seduma.yucatan.gob.mx/cenotes-grutas/index.php [Accessed 13 December 2017].

Shen, H., Huang, Y., Wang, R., Zhu, D., Li, W., Shen, G., et al. (2013) Global atmospheric emissions of polycyclic aromatic hydrocarbons from 1960 to 2008 and future predictions. Environmental Science and Technology, 47(12), 6415-6424. Available at: https://doi.org/10.1021/ es400857z.

Szeroczyńska, K. and Zawisza, E. (2015) Cenotes - Lakes of the Yucatan Peninsula (Mexico). Studia Quaternaria, 32(1), 53-57. Available at: https://doi.org/10.1515/ squa-2015-0005.

Tongo, I., Ogbeide, O. and Ezemonye, L. (2017) 'Human health risk assessment of polycyclic aromatic hydrocarbons (PAHs) in smoked fish species from markets in Southern Nigeria. Toxicology Reports, 4, 55-61. Available at: https://doi.org/10.1016/j. toxrep.2016.12.006.

United States Environmental Protection Agency (2009) Polycyclic Aromatic Hydrocarbons (PAHs) Fact Sheet. Available at: https://www.epa.gov/sites/production/files/ 2014-03/documents/pahs_factsheet_cdc_2013.pdf [Accessed 13 September 2017].

Van Hengstum, P.J., Reinhardt, E.G., Beddows, P.A., Schwarcz, H.P. and Gabriel, J.J. (2009) Foraminifera and testate amoebae (thecamoebians) in an anchialine cave: Surface distributions from Aktun $\mathrm{Ha}$ (Carwash) cave system, Mexico. Limnology and Oceanography, 54(1), 391-396. Available at: https://doi.org/10.4319/ 10.2009.54.1.0391.

Vidal, L., Vallarino, A., Benítez, I. and Correa, J. (2015) Implementation of the Ramsar strategic plan in coastal wetlands of the Península de Yucatán: regulations and normativity. Latin American Journal of Aquatic Research, 43(5), 873-887. Available at: https://doi.org/10.3856/ vol43-issue5-fulltext-7.

Villafañe, V.E., Guendulain-García, S.D., Valadez, F., RosilesGonzález, G., Helbling, E.W. and Banaszak, A.T. (2015) Antagonistic and synergistic responses to solar ultraviolet radiation and increased temperature of phytoplankton from cenotes (sink holes) of the Yucatán Peninsula, México. Freshwater Science, 34(4), 1282-1292. Available at: https://doi.org/10.1086/682051.

Villalobos-Zapata, G.J., Mendoza Vega, J. (Coord.) (2010) La Biodiversidad en Campeche: Estudio de Estado, La biodiversidad en Campeche. Estudio de Estado. ISBN 978-607-7887-21-8.

World Health Organization (2015) Bull World Health Organ. Available at: https://doi.org/10.2471/BLT.15.152710.

World Health Organization (2017) Tuberculosis nota descriptive. Available at: http://www.who.int/mediacentre/ factsheets/fs104/es/. 